\title{
DESIGN PROCEDURE FOR LOADING CAPACITY CALCULATIONS FOR CLASSIC AUTOMOBILE DIFFERENTIALS
}

\section{VLADIMÍR MORAVEC, ZDENĚK FOLTA, PETR MARŠÁLEK}

VŠB-Technical University of Ostrava, Faculty of Mechanical Engineering, Department of Machine Parts and Mechanisms, 17. listopadu 15, 70833 Ostrava-Poruba, Czech republic

E-mail:vladimir.moravec@vsb.cz, zdenek.folta@vsb, petr.marsalek@vsb.cz.

\section{SHRNUTÍ}

Článek se zabývá návrhem dimenzování ozubení pro různé typy automobilních diferenciálů a děličů momentů. V navrženém postupu jsou použity nejnovější výpočtové postupy podle norem ISO a DIN. Do výpočtu jsou aplikována hypotetická spektra provozního zatižení, která jsou odvozena od vlastních měření.

\section{KLíČOVÁ SLOVA: OZUBENII, DIFERENCIÁL, DĚLIČ MOMENTU, ÚNOSNOST, SPEKTRUM ZATIZŽENÍ, ŽIVOTNOST}

\section{ABSTRACT}

This article deals with the procedure for loading capacity calculation for various types of automobile differentials and torque dividers. The latest calculation methods in accordance with ISO and DIN standards are applied in this procedure. Hypothetical spectra of working load derived from own measurements are applied.

\section{KEYWORDS: GEARS, DIFFERENTIAL, TORQUE DIVIDER, LOADING CAPACITY, LOADING SPECTRUM, SERVICE LIFE}

The proposed calculation procedures relate to a differential with spur and bevel gears and various division ratios of torque. The division ratio is defined by relationships $J_{\mathrm{D}}=T_{1} / T_{2} \geq 1 ; T_{1} \geq T_{2^{\prime}}$; $T_{\mathrm{U}}=T_{1}+T_{2^{\prime}}$ where indexes 1,2 are marked with an output torque, and their sum $T_{\mathrm{U}}$ is usually torque $\mathrm{n}$ on the planet carrier. Gears of mechanical differentials are significantly different from other gear drives, because they have a specific mesh and method of loading.

TABLE 1: Examples of basic car drive variants

TABULKA 1: Př́klady základních variant pohonu automobilu

\begin{tabular}{|c|c|c|}
\hline $\begin{array}{l}\text { type of } \\
\text { engine }\end{array}$ & \\
\hline
\end{tabular}

The relative circumferential speeds are very low; for example, the gears of an axis differential have a relative circumferential velocity close to zero when driving straight ahead. Frequencies of load cycles at all load levels are very low and therefore the design approach differs from classic kinematic gears. The vehicle drive train scheme can be very diverse with a variety of differentials location, as shown in Table 1.

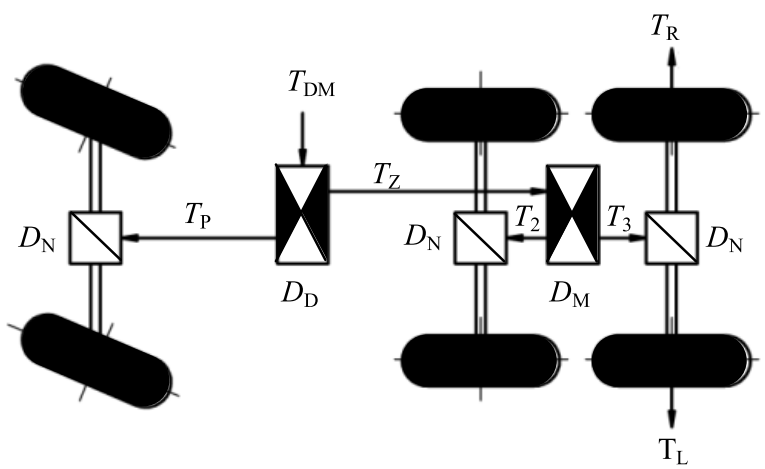

FIGURE 1: Drive train scheme for $6 \times 6$ vehicles OBRÁZEK 1: Schéma pohon u vozidla $6 \times 6$

The scheme for fully $6 \times 6$ vehicles is shown in Figure 1, where each differential type is marked. 
$D_{\mathrm{D}}$. torque divider $J_{\mathrm{D}}=T_{\mathrm{Z}} / T_{\mathrm{P}} \geq 1$

$T_{\mathrm{Z}}$...drive of rear two axles (tandem) [Nm]

$T_{\mathrm{p}} \ldots$ drive of front axle $[\mathrm{Nm}]$

$D_{\mathrm{M}}$...inter-axle differential (divider) $J_{\mathrm{D}}=T_{2} / T_{3}=1$

$D_{\mathrm{N}} \cdots$ axle differential $J_{\mathrm{D}}=T_{\mathrm{R}} / T_{\mathrm{L}}=1$

$T_{\mathrm{R}^{\prime} \mathrm{L}} \ldots$ driving torques for right ( $\left.\mathrm{R}\right)$ and left $(\mathrm{L})$ axle shaft $[\mathrm{Nm}]$

The following are examples of some mechanical differentials and their power loads. An example of a frequently used design for an axial differential with bevel gears and four planets is shown in Figure 2.

The scheme and design of a differential with spur gears and division ratio $J_{\mathrm{D}}=1$ as shown in Figure 3 is used less frequently. The design of a differential lock that provides connection between carrier with sun gear is shown in Figure 3. The differential locks are used primarily in off-road vehicles, where there is a risk of reduced mobility when the wheels slip. When the differential lock is used on a road with high adhesion, parasitic torques arise and increases the gear load.
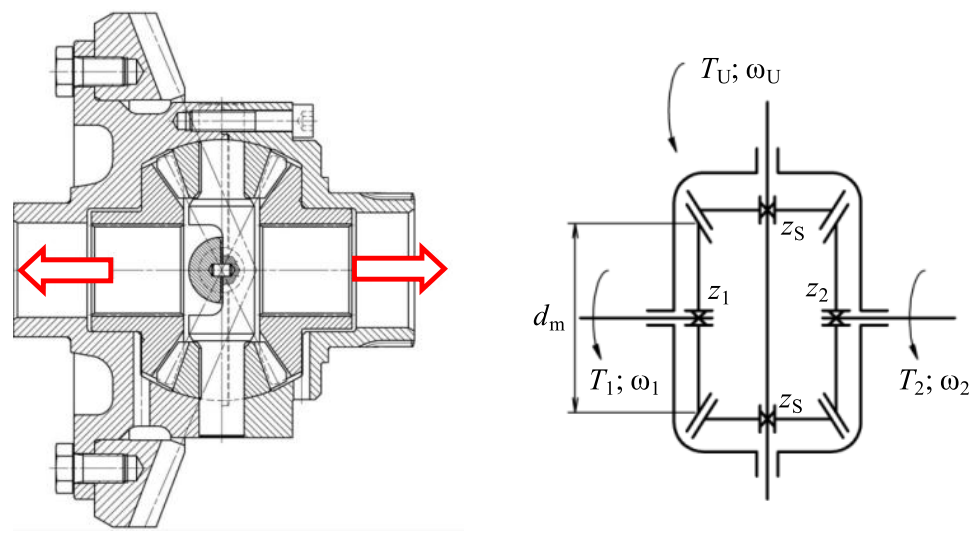

$$
\begin{aligned}
& z_{1}=z_{2} \\
& J_{\mathrm{D}}=1 \\
& T_{\mathrm{U}}=T_{1}+T_{2}[\mathrm{Nm}] \\
& \omega_{u}=\frac{\omega_{1}+\omega_{2}}{2} \quad\left[\mathrm{~s}^{-1}\right]
\end{aligned}
$$

FIGURE 2: Scheme and design of axis differential with bevel gears OBRÁZEK2:Příkladkonstrukčníhořešeníkuželovéhoosovéhodiferenciálu
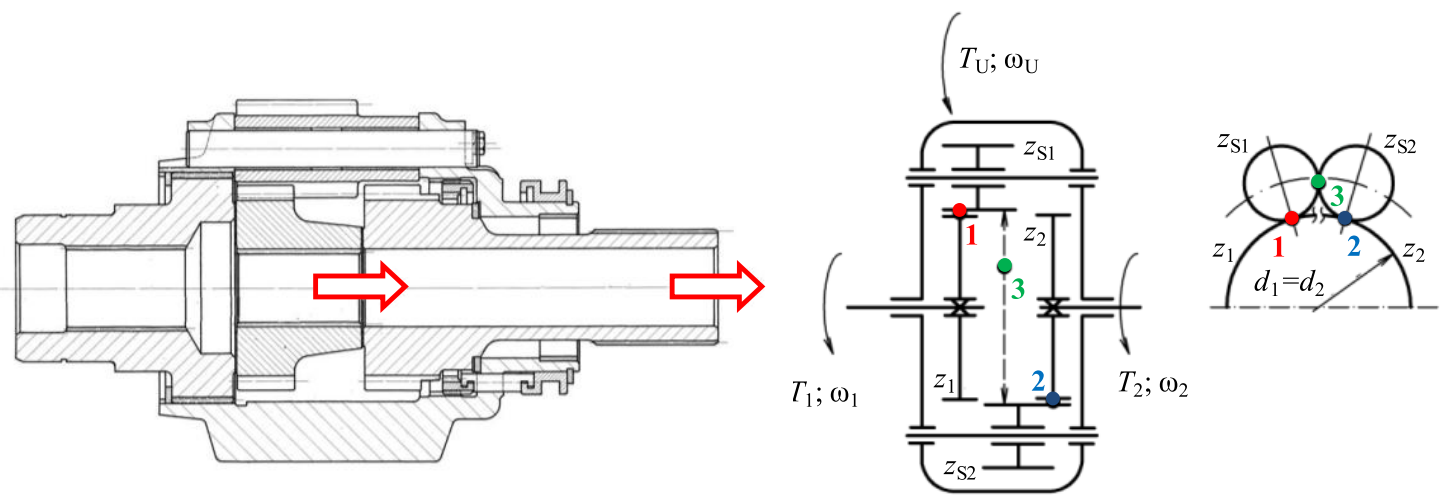

$$
\begin{aligned}
& z_{1}=z_{2} \\
& J_{\mathrm{D}}=1 \\
& T_{\mathrm{U}}=T_{1}+T_{2}[\mathrm{Nm}] \\
& \omega_{\mathrm{U}}=\frac{\omega_{1}+\omega_{2}}{2}\left[\mathrm{~s}^{-1}\right]
\end{aligned}
$$

FIGURE 3: Scheme a design of a differential with spur gears

OBRÁZEK 3: Schéma a př́klad konstrukčního řešení diferenciálu s čelnímikoly
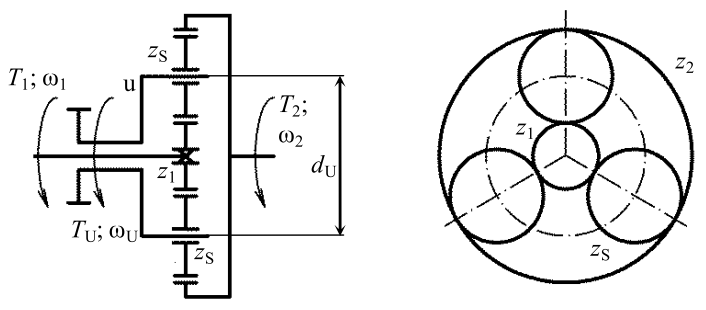

$$
\begin{aligned}
& \left|z_{2}\right| \gg z_{1} \\
& J_{\mathrm{D}}=\frac{\left|z_{2}\right|}{z_{1}} \doteq 1,75 \sim 5 \\
& T_{\mathrm{U}}=T_{1}+T_{2}[\mathrm{Nm}]
\end{aligned}
$$


A torque divider (inter-axle differential) is used to drive the front and rear axles for $J_{\mathrm{D}}>>1$. The division ratio is dependent on the engine and the total power load, or on the load ratio of the rear and front axles. The mechanical torque divider is implemented using the planet as shown in Figure 4.

The division ratio is $J_{\mathrm{D}} \doteq 1.7 \sim 5$. Most transmissions have $J_{\mathrm{D}} \doteq 2$ for application on a $4 \times 4$ with rear double mounting or $6 \times 6$ with simple mounting. The ratio of axle load when applied to a $6 \times 6$ with rear double mounting for off-road vehicles (dump trucks) can be considerably greater $J_{\mathrm{D}} \doteq 3 \sim 5$. When deciding on the choice of divider the fact that in practically all driving modes the rear axle is overload due to acceleration, group, etc. should be taken into account. An applied example of inter-axle differential $J_{\mathrm{D}} \doteq 2$ is shown in Figure 5 .

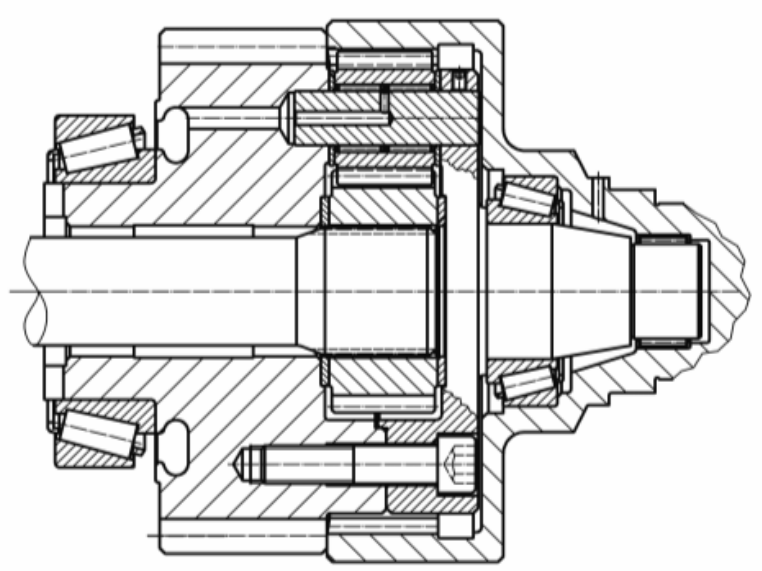

FIGURE 5: Inter-axle differential with division ratio $J_{\mathrm{D}} \doteq 2$

OBRÁZEK 5: Mezinápravový diferenciál s poměrem dělení $J_{\mathrm{D}} \doteq 2$

The load of the differential for dimensioning of parts is very difficult to define. Maximum torque from the motor and adhesive load, which has an influence on the differential box (cage), is usually determined according to Table 1. Let's suppose that the differential is loaded from the engine torque acting on the differential cage as per the following equation:

$T_{\mathrm{DM}}=T_{\mathrm{M}} \times i_{\mathrm{DM}} \times m_{\mathrm{D}} \times \eta_{\mathrm{DM}}$

where

$T_{\mathrm{M}} \quad$ maximum engine torque $[\mathrm{Nm}]$,

$i_{\mathrm{DM}} \quad$ maximum ratio between the engine and differential cage [-],

$m_{\mathrm{D}} \quad$ proportion of the torque corresponding to the controlled differential [-]

$\eta_{\mathrm{DM}}=1$, for comparative calculation the efficiency is usually neglected.
For example, from Figure 1 it will follow that:

- drivetrain $4 \times 2 m_{\mathrm{D}}=1$ (for front and rear);

- drivetrain $4 \times 4 m_{\mathrm{D}}=0.5$ for divider $J_{\mathrm{D}}=1$

- drivetrain $6 \times 6$ for divider with performance $J_{\mathrm{D}} \neq 1, m_{\mathrm{Dp}}=$ $1 /\left(1+J_{\mathrm{D}}\right), m_{\mathrm{Dp}}=J_{\mathrm{D}} /\left(1+J_{\mathrm{D}}\right)$. This means that if $J_{\mathrm{D}}=2$ then $m_{\mathrm{Dp}}=0.33$ for front axle and $m_{\mathrm{Dz}}=0.67$ for rear axle.

If the vehicle isn't equipped with an inter-axle differential (divider), then hypothetically we can assume that the division ratio $J_{\mathrm{D}}$ is given by the axle load ratio $J_{\mathrm{D}}^{\prime}=\mathrm{G}_{\mathrm{z}} / \mathrm{G}_{\mathrm{p}}$. If the front axle drive can be turned off, then according to the cited relationships $m_{\mathrm{p}}=1 /\left(1+J_{\mathrm{D}}^{\prime}\right)$ and $m_{\mathrm{z}}=1$ for drivetrain $4 \times 4$ or $m_{\mathrm{z}}=0.5$ for drivetrain $6 \times 6$. Similarly, for the drivetrain $8 \times 8$. This reasoning is valid providing that the inter-axle in a double-axle always has ratio $J_{\mathrm{D}}=1$.

Control of a differential torque transmission is performed by calculating adhesion torque according to the equation:

$T_{\mathrm{DA}}=G_{\mathrm{N}} \times g \times \varphi \times R_{\mathrm{d}} \times \frac{1}{i_{\mathrm{N}}}=9,81 \times G_{\mathrm{N}} \times \frac{R_{\mathrm{d}}}{i_{\mathrm{N}}},[\mathrm{Nm}]$

where

$G_{\mathrm{N}}$ axle or double-axle load driven by differential [kg],

$g$ gravitational acceleration [ $\mathrm{m} \times \mathrm{s}^{-2}$,

$\varphi=1$ agreed coefficient of adhesion [-],

$R_{\mathrm{D}} \quad$ dynamic radius of tire [m],

$i_{\mathrm{N}} \quad$ ratio between solved differential and tire [-].

Load of axle or double-axle is usually chosen according to the static weight distribution. The actual dynamic load changes in traffic. Rear axles are loaded more precisely in the limit state (maximum) such as when riding up a hill, overloaded or during acceleration. For evaluation the load capacity can be used for the front differential axle (axles) taking into account the static load $G_{\mathrm{N}}=G_{\mathrm{p}}$. To calculate the adhesion torque of the rear axle (axles) a higher static load can be assumed than the static load where the ratio is about $\delta_{\mathrm{Nz}}=(1.1 \div 1.5)$ thus $G_{\mathrm{N}}=(1.1 \div 1.5)$, where $G_{\mathrm{P}}$ and $G_{\mathrm{Z}}$ are nominal static axle (axles) loads. This is especially true where over loading of the rear axles is not considered. The

TABLE 2: Allowable load of differential torque TABULKA 2: Mezní zatížení moment diferenciálu

\begin{tabular}{lll}
\hline torques ratio & torques size & Recommendations for design \\
\hline$T_{\mathrm{DM}}<T_{\mathrm{DA}}$ & $T_{\mathrm{D}}=T_{\mathrm{DM}}$ & front and rear axle \\
\hline$T_{\mathrm{DM}}>>T_{\mathrm{DA}}$ & $T_{\mathrm{D}}=T_{\mathrm{DA}}$ & only front axle \\
\cline { 2 - 3 } by more than & $T_{\mathrm{D}}=(1,1 \div 1,5) T_{\mathrm{DA}}$ & rear axle \\
\hline $50 \%$ & $T_{\mathrm{D}}=\frac{T_{\mathrm{DM}}+T_{\mathrm{DA}}}{2}$ & rear axle \\
\hline $\begin{array}{l}T_{\mathrm{DM}} \geq T_{\mathrm{DA}} \\
\text { to } 50 \%\end{array}$ & & \\
\hline
\end{tabular}




\begin{tabular}{|c|c|c|}
\hline Type of differential & Origin of force on drive differential element $d$ [mm] & Coefficient of uneven force distribution [-] \\
\hline Bevel & $\begin{array}{l}d_{m}=m_{\mathrm{n}} \times z \\
\text { middle pitch diameter of central wheel }\end{array}$ & $\begin{aligned} \delta=1 \text { for } n & =2 \text { or for } \\
n & =4-\text { free pin } \\
\delta \doteq 1.2 \text { for } n & =4-\text { rigid pin }\end{aligned}$ \\
\hline Spur (straight teeth) & $\begin{array}{l}d=m_{\mathrm{n}} \times z_{12} \\
\text { pitch diameter of central wheel }\end{array}$ & \multirow{2}{*}{$\begin{array}{l}\delta=1 \text { for } n=2,3 \\
\delta \doteq \mathrm{n} /(\mathrm{n}-1) \text { for } n>3\end{array}$} \\
\hline Planetary & $\begin{array}{l}d=d_{\mathrm{U}} \dot{=} m_{\mathrm{n}} \times\left(z_{1}+z_{\mathrm{s}}\right) \\
\text { center distance between satellite pins }\end{array}$ & \\
\hline
\end{tabular}

resulting agreed torques acting on a planet carrier (differential cage) for the comparative strength calculations are summarized for various operating conditions in Table 2 .

The forces between the teeth of all the differentials are given by the equation:

$F_{\mathrm{T}}=\frac{2000 \times T_{\mathrm{U}} \times \delta}{d \times n},[\mathrm{~N}]$

where

$T_{\mathrm{U}}=T_{\mathrm{D}}$ torque moment on the driving element of a differential given by Table 2[Nm],

$n$ number of planetary gears or pairs of planetary gears[-],

$\delta \quad$ degree of inequality of a force distribution (Table 3)[-],

$d \quad$ reference or the pitch diameter of driving element of a differential [mm].

The rotation load of differential gears, such as number of cycles, differs significantly over a variety of vehicle driving conditions.
Rotations of the differential gear are theoretically zero when driving is straight. The spinning of the differential gear occurs under the following conditions:

- driven wheel tires have different rolling radii and different load,

- driven wheels or axles move along an unequal length of the roadway (curves, transverse and longitudinal irregularities),

- uneven traction of tires on one axle (or axles for interaxle differentials) due to uneven adhesion or different characteristics of tire slip.

The rotation frequency of differential gears depends on speed, vehicle load, traffic density, climatic conditions and other factors (adhesion, uneven off-road). Determining the load spectrum for differential gears (with respect to load cycles or rotations on load) is very difficult. For orientation and a basic idea of all relationships, load characteristics were measured on a Škoda Fabia car. During the measurements instantaneous values of rotations on the left and right wheel axles were directly recorded. The value of the rotations difference is positive or negative. When calculating the

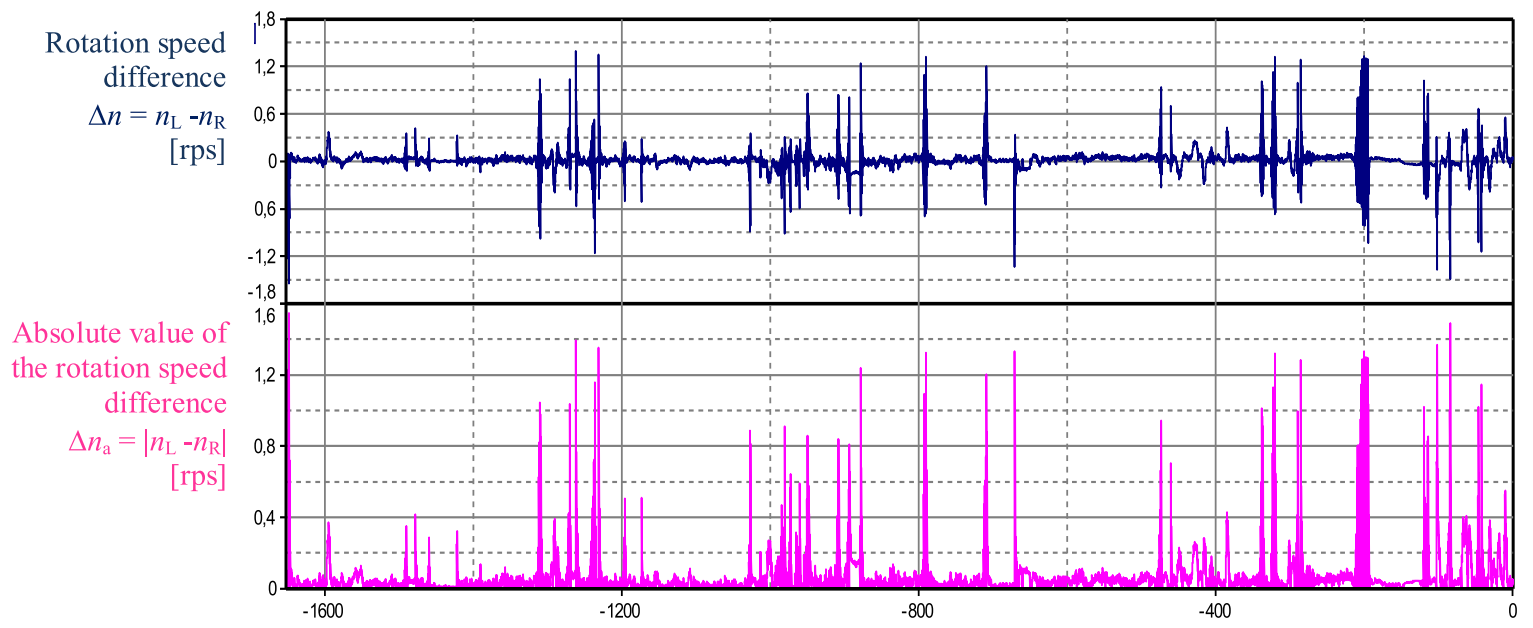

FIGURE 6: Evaluation of recorded differences in rotations from the left and right wheel OBRÁZEK 6: Vyhodnocení záznam urozdílu otáček zlevého a pravého kola 


\begin{tabular}{|c|c|c|c|c|c|c|c|}
\hline \multirow{3}{*}{ Type of roadway } & \multirow{3}{*}{ Measured section } & \multicolumn{2}{|c|}{ Measured values } & \multicolumn{4}{|c|}{ Calculated values } \\
\hline & & \multirow[t]{2}{*}{$\begin{array}{c}\text { travel time } \\
t \\
{[\mathrm{~s}]}\end{array}$} & \multirow[t]{2}{*}{$\begin{array}{c}\text { average speed } \\
v_{p} \\
{[\mathrm{~km} / \mathrm{h}]}\end{array}$} & \multirow[t]{2}{*}{$\begin{array}{l}\begin{array}{c}\text { length } \\
\text { of the section }\end{array} \\
1=\frac{v_{\mathrm{p}} \times t}{3600} \\
{[\mathrm{~km}]}\end{array}$} & \multirow[t]{2}{*}{$\begin{array}{c}\text { difference of } \\
\text { rotations } \\
\Delta n_{\mathrm{a}}=\left|n_{\mathrm{L}}-n_{\mathrm{R}}\right| \\
{\left[\mathrm{s}^{-1}\right]}\end{array}$} & \multicolumn{2}{|c|}{$\begin{array}{c}\text { rotations of central wheel } \\
\text { on } 1 \mathrm{~km} \\
\Delta n_{\mathrm{i}}=\frac{\Delta n_{\mathrm{a}} \times 3600}{v_{\mathrm{p}}} \\
{[\mathrm{rot} / \mathrm{km}]}\end{array}$} \\
\hline & & & & & & in section & average \\
\hline \multirow{3}{*}{ motorway } & motorway to Bohumín I & 102.14 & 86.16 & 2.44 & 0.08473 & 3.540 & \multirow{3}{*}{3.083} \\
\hline & motorway to Bohumín II & 463.58 & 81.23 & 10.46 & 0.03458 & 1.532 & \\
\hline & Klimkovice - Pustiměř & 3600.0 & 122.35 & 122.35 & 0.14194 & 4.177 & \\
\hline \multirow{4}{*}{ town } & Přívoz - areal VŠB-TU & 1653.0 & 32.81 & 15.06 & 0.06741 & 7.397 & \multirow{4}{*}{9.059} \\
\hline & centrum - Michálkovice & 1136.0 & 30.06 & 9.49 & 0.08522 & 10.206 & \\
\hline & Michálkovice - Radvanice & 1601.0 & 28.97 & 12.88 & 0.08929 & 11.093 & \\
\hline & Radvanice - areal VŠB-TU & 1239.6 & 31.34 & 10.79 & 0.06564 & 7.541 & \\
\hline \multirow{2}{*}{$\begin{array}{l}\text { roadway class } \\
\text { I outside the city }\end{array}$} & areal VŠB-TU - Petřvald & 1386.34 & 43.25 & 16.65 & 0.05033 & 4.190 & \multirow{2}{*}{5.275} \\
\hline & Petřvald - Kopřivnice & 1004.91 & 52.29 & 14.60 & 0.09237 & 6.360 & \\
\hline roadway class II & Opava-Bílovec & 2068.4 & 50.00 & 28.73 & 0.08112 & 5.841 & 5.841 \\
\hline \multicolumn{7}{|l|}{ Total traffic } & 5.815 \\
\hline
\end{tabular}

differential loads, differences in the absolute value of the rotation difference between the left and the right half axle: $\Delta n_{\mathrm{a}}=\left|n_{\mathrm{L}}-n_{\mathrm{R}}\right|$ are also taken into account.

An example of difference and frequency of rotations of automobile wheels during city driving is shown in Figure 6.

TABLE 5: Load spectrum parameters TABULKA 5: Parametry spekter zatížení

\begin{tabular}{|c|c|c|c|c|}
\hline \multirow[b]{2}{*}{ type of roadway } & \multirow[b]{2}{*}{$\begin{array}{l}\text { maximal } \\
\text { torque } \\
M_{\mathrm{p}}[\mathrm{Nm}]\end{array}$} & \multicolumn{2}{|c|}{$\begin{array}{l}\text { relative number of } \\
\text { spectrum cycles }\end{array}$} & \multirow{2}{*}{$\begin{array}{c}\text { degree } \\
\text { of spectrum } \\
\text { aggressiveness } \\
s\end{array}$} \\
\hline & & $\begin{array}{c}\text { for } \\
\text { maximal } \\
\text { load } \\
\overline{\bar{N}_{\mathrm{p}}}\end{array}$ & $\frac{\text { total }}{N_{\mathrm{C}}}$ & \\
\hline motorway & 970 & $1 \times 10^{-3}$ & 1 & 2.2 \\
\hline town & 1650 & $1.2 \times 10^{-5}$ & 1 & 1.2 \\
\hline roadway class I & 1150 & $1 \times 10^{-5}$ & 1 & 1.9 \\
\hline roadway class II & 1350 & $3 \times 10^{-4}$ & 1 & 1.07 \\
\hline $\begin{array}{l}\text { total with } \\
\text { weight } 0.25\end{array}$ & 1620 & $1.72 \times 10^{-6}$ & 1 & 1.3 \\
\hline
\end{tabular}

For the assessment of differential gear life it is necessary to determine the frequency rather than speed differential, depending on distance traveled. The log records the measured values of the average velocity $v_{\mathrm{p}^{\prime}}$ time driving $t$ and the average value of the relative rotation $\Delta n_{\mathrm{a}}$, which was evaluated for each type of driving in Table 4. This Table lists the driving evaluated by calculating resulting frequency of sun gear rotations in test vehicles per $1 \mathrm{~km}$. For lifetime calculation of differential gears a hypothetical load spectrum was created frommeasured values on a car, see Table 4 . The load spectrum is usually expressed as torque as a function of the number of cycles (in absolute or relative values) for a defined roadway. For further use in the lifetime calculations, mathematical compensation for load spectrum was performed using the equation:

$N_{\mathrm{i}}=N_{\mathrm{C}}\left(\frac{N_{\mathrm{p}}}{N_{\mathrm{C}}}\right)^{\left(\overline{M_{\mathrm{i}}}\right)^{\mathrm{s}}}$,

where

$N_{i} \quad$ cumulative number of load cycles on the i-th level,

$N_{C} \quad$ total number of spectrum cycles,

$N_{p} \quad$ number of cycles at the highest level,

$\frac{{ }_{P}}{M_{i}} \quad$ relative medium torque on the i-th level,

$s \quad$ degree of spectrum aggressiveness. 


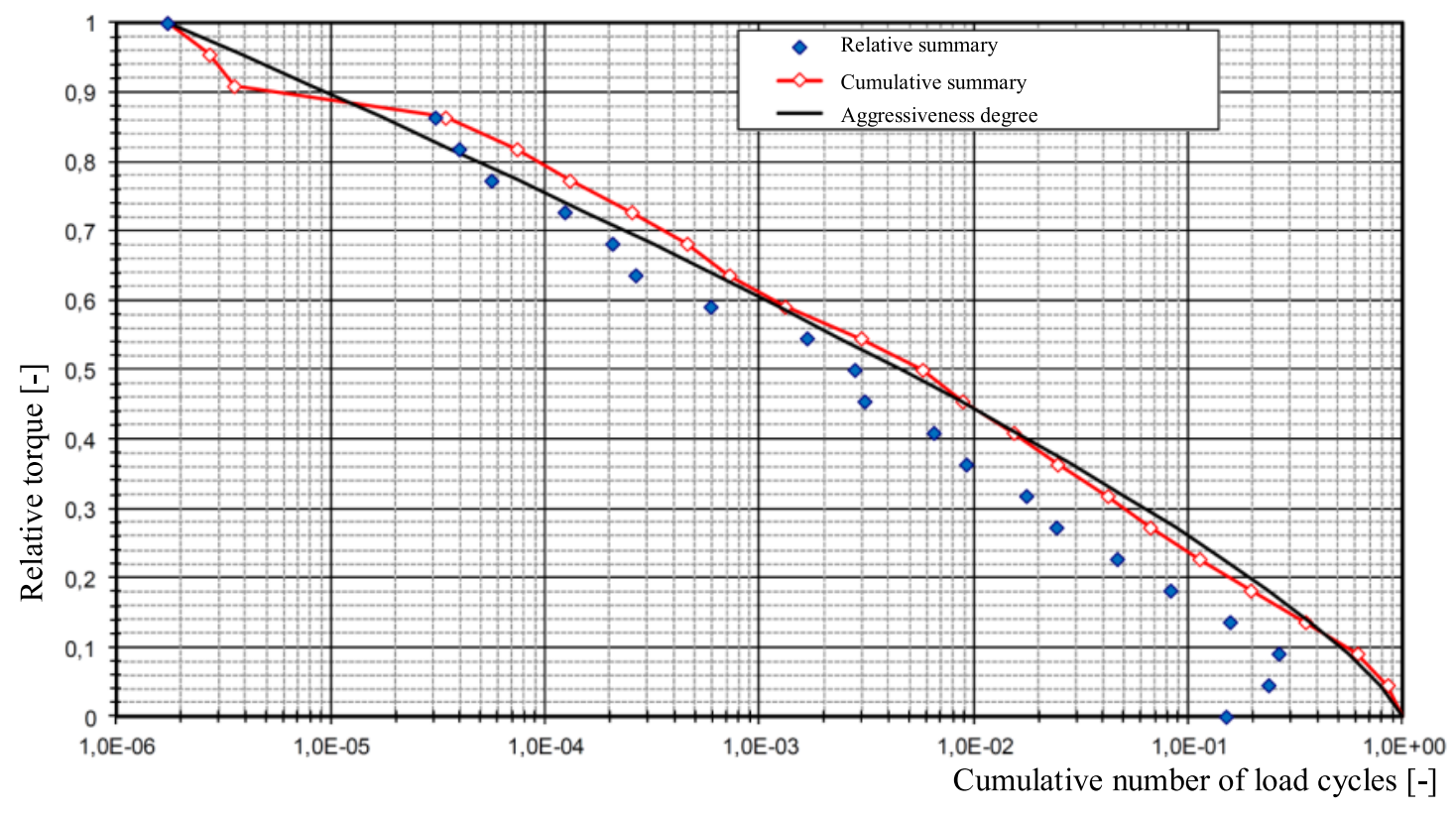

FIGURE 7: Relative cumulative frequency of torque level

OBRÁZEK 7: Poměrná kumulativní četnost výskytu hladiny momentu

For each type of road specified in Table 4 the load spectrum was evaluated (torque in relation to the cumulative number of cycles). Subsequently a substitution was performed according to the relationship with the parameters in Table 5 . The measured values of the spectrum sum and their total compensation are shown in Figure 7.

The plot of the relative load spectrum from the measured values can be hypothetically accepted as a basis for estimating the load of all types of vehicles with regard to their specific destination. The maximum load corresponds to the maximum torque specified in Table 1. The number of cycles can be derived for sun gear from speed per 1 kilometer (Table 4) times the estimated expected life of the vehicle in kilometers. The estimated number of cycles of load spectrum for the basic vehicle types is shown in Table 6.

The design of automotive differential gears requires a different approach to other drive aggregates of vehicles for the following reasons:
- the frequency of maximum load for differential gears is low and it is used to reduce by tire adhesion,

- the number of loading cycles is derived from the rotation difference of driven parts (axles, half-axles) and is very low,

- formation of higher relative rotation from high torque is unlikely,

- no internal dynamic forces arise because circumferential velocities are very low during differential gears meshing. Gears of automobile differentials are loaded in low cycle fatigue. This means that the maximum stress occurs when the number of cycles is in the order of lower than 104 cycles. Load control is performed by modified procedures according to DIN 3990-T41, which is practically identical to ISO 6336, which is intended for the design of automobile gears.

For comparative calculations of allowable stress of differential gears, factors influencing additional load due to bending and contact can be neglected

TABLE 6: Estimated number of cycles for vehicle load spectrum

TABULKA 6: Odhady počtů cyklů spekter zatižení automobilů

\begin{tabular}{|c|c|c|c|}
\hline & \multicolumn{3}{|c|}{ Vehicle type } \\
\hline & Personal automobile & Van & Truck \\
\hline Estimate of expected life $L_{\mathrm{D}}[\mathrm{km}]$ & $2.5 \times 10^{5}$ & $5 \times 10^{5}$ & $2 \times 10^{6}$ \\
\hline Mean value of rotation $\Delta n_{\mathrm{si}}$ [cycles $\left./ \mathrm{km}\right]$ & $\begin{array}{c}3 \div 5 \\
\text { (measured) }\end{array}$ & $\begin{array}{c}5 \div 10 \\
\text { (measured) }\end{array}$ & $\begin{array}{c}10 \div 20 \\
\text { (estimated) }\end{array}$ \\
\hline Total length of spectrum $N_{\mathrm{C}}=L_{\mathrm{D}} \times \Delta n_{\mathrm{si}}$ [cycles] & $7.5 \times 10^{5} \div 1.3 \times 10^{6}$ & $2.5 \times 10^{6} \div 5 \times 10^{6}$ & $2 \times 10^{7} \div 4 \times 10^{7}$ \\
\hline Total number of cycles at maximum load level in lifetime $N_{\mathrm{p}}$ [spectrum] & $7.5 \div 13$ & $25 \div 50$ & $200 \div 400$ \\
\hline
\end{tabular}


$K_{\mathrm{F}}=K_{\mathrm{A}} \times K_{\mathrm{Fv}} \times K_{\mathrm{F} \beta}=K_{\mathrm{F} \alpha}=K_{\mathrm{H}}=K_{\mathrm{A}} \times K_{\mathrm{Hv}} \times K_{\mathrm{H} \beta} \times K_{\mathrm{H} \alpha}=1$

To calculate the bending stress of an automobile differential gear it is appropriate to use the DIN 3390-3 method C, which considers the force on the head of the tooth according to Figure 8. Bending stress in gears with straight teeth will equal

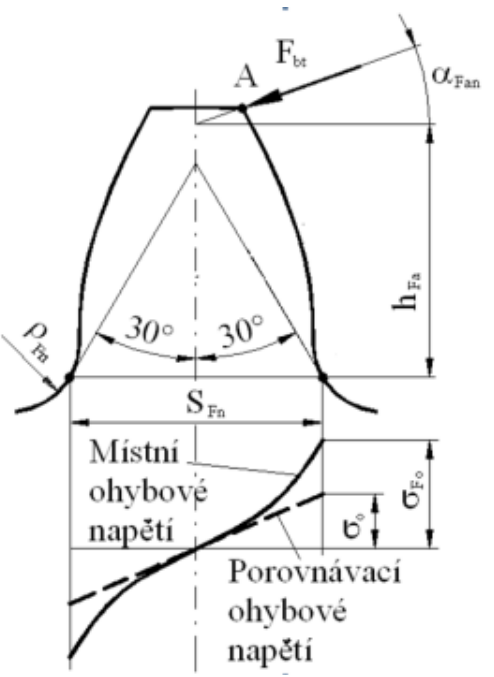

FIGURE 8: Scheme of tooth load for the calculation of bending stress OBRÁZEK 8: Schéma zatížení zubu pro výpočet napětí v ohybu

$$
\sigma_{\mathrm{F}}=\frac{F_{\mathrm{T}}}{b_{\mathrm{F}} \times m_{\mathrm{n}}} \times Y_{\mathrm{Fa}} \times Y_{\mathrm{Sa}} \times Y_{\varepsilon}
$$

where

$F_{\mathrm{T}}=\frac{2000 \times T_{\mathrm{D}}}{d}-$ tangential load $[\mathrm{N}]$

$T_{\mathrm{D}} \quad$ agreed torque according to differential type [Nm],

$b_{\mathrm{F}} \quad$ tooth width for calculation of the bending stress [mm]

$m_{n} \quad$ normal module $[\mathrm{mm}]$

$d$ reference diameter of drive differential element [mm]

Coefficients for the calculation of bending stress:

$Y_{F a}=6 \times \frac{\frac{h_{F a}}{m_{n}} \times \cos \alpha_{F a n}}{\left(\frac{s_{F n}}{m_{n}}\right)^{2} \times \cos \alpha_{n}}-$ form factor,

$Y_{\varepsilon}=0,25+\frac{0,75}{\varepsilon_{\alpha}}-\begin{gathered}\text { contact ratio factor, where } \varepsilon_{\alpha}-\text { transverse } \\ \text { contact ratio, }\end{gathered}$
$Y_{S a}=\left(1,2+0,13 \times \frac{s_{F n}}{h_{F a}}\right) \times \frac{s_{F n}}{2 \times \rho_{F n}}\left(\frac{1}{1,21+\frac{2,3 h_{F a}}{s_{F n}}}\right)$

- stress correction factor

Calculation of the limit contact stress (modified Hertzian relationship) to the tooth contact is given by the equation:

$\sigma_{H}=Z_{H} \times Z_{E} \times Z_{\varepsilon} \times \sqrt{\frac{F_{t}}{d \times b} \times \frac{u+1}{u}}$

where

$F_{t} \quad$ tangential load identical with calculation of bending stress,

d planet reference diameter (virtual gears for bevel gears) $[\mathrm{mm}]$,

$b$ tooth width for calculating the contact stress [mm],

$u \quad$ gear ratio $z_{1} / z_{2}$ and virtual gears for bevel gears $z_{\mathrm{v} 1} /$

$Z_{H}=\sqrt{\frac{z_{\mathrm{v} 2}}{\cos ^{2} \alpha_{t} \times \sin \alpha_{w t}}}-$ zone factor,

$Z_{E}=190[\mathrm{MPa}]-($ steel-steel $)-$ elasticity factor,

$Z_{\varepsilon}=\sqrt{\frac{4-\varepsilon_{\alpha}}{3}}-$ contact ratio factor.

Determination of allowable bending stress and contact based on the fatigue properties is set out in the cited ISO and DIN standards. Gears of automotive differentials are made almost entirely of carburizing steels alloyed with $\mathrm{Cr}-\mathrm{Mo}$ or $\mathrm{Cr}-\mathrm{Mn}$ with medium quality (MQ). Fatigue properties in bending and contact can generally be described by the diagram in Figure 9 and data according to Table 6.

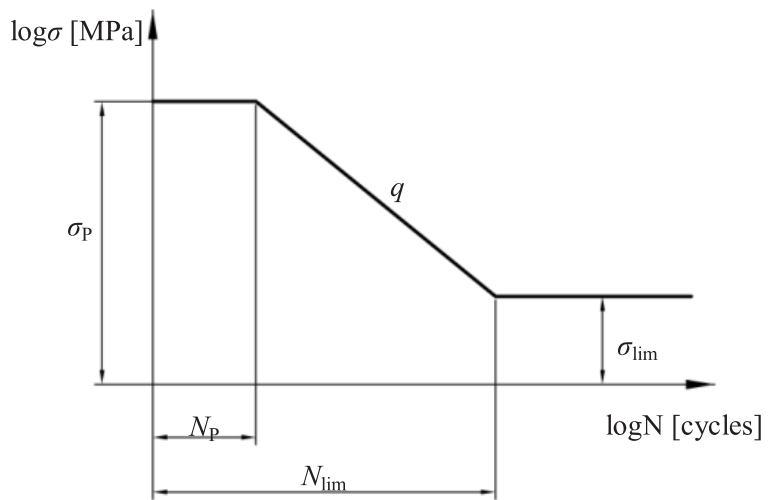

FIGURE 9: Fatigue properties of differentials OBRÁzEK 9: Únavové vlastnosti ozubených kol diferenciálů 
Parameters of S-N curves for gear materials $20 \mathrm{MnCr} 5$ (1.7147) and $20 \mathrm{MoCr} 4$ (1.7321) are directly determined and shown in the summary Table 6 according standard DIN 3990-41. Fatigue limit in bending $s_{\mathrm{FE}}$ is defined in the ISO standard in terms of amplitude, but standards DIN and ČSN indicate pulsating cycles where the following applies:

$\sigma_{\mathrm{FEN}}=2 \times \sigma_{\text {Flim }}$

Fatigue limit in bending and contact simply marked $s_{\text {lim }}$ are shown in Table. 6.

$\sigma_{\mathrm{P}}=\sigma_{\mathrm{FEN}} \times Y_{\mathrm{NT}}$

for bending,

$\sigma_{\mathrm{P}}=\sigma_{\mathrm{Hlim}} \times Z_{\mathrm{NT}}$

for contact.

TABLE 7: Fatigue characteristics of hardened gears

TABULKA 7: Únavové charakteristiky cementovaných ozubených kol

\begin{tabular}{l|c|c|c|c}
\hline \multirow{2}{*}{$\begin{array}{l}\text { Common } \\
\text { parameter of S-N } \\
\text { curve }\end{array}$} & \multicolumn{2}{|c|}{ Bending } & \multicolumn{2}{c}{ Contact } \\
\cline { 2 - 5 } & $\begin{array}{c}\text { ISO } \\
6336-5\end{array}$ & $\begin{array}{c}\text { DIN } \\
3990-41\end{array}$ & $\begin{array}{c}\text { ISO } \\
6336-5\end{array}$ & $\begin{array}{c}\text { DIN } \\
3990-41\end{array}$ \\
\hline Vickers [HRC] & \multicolumn{2}{|c|}{$58 \div 64$} & \multicolumn{2}{c}{$58 \div 64$} \\
\hline$\sigma_{\text {lim }}[\mathrm{MPa}]$ & $922(1000)$ & 920 & \multicolumn{2}{c}{1500} \\
\hline$\sigma_{\mathrm{p}}[\mathrm{MPa}]$ & - & $1840(2300)$ & - & 2400 \\
\hline$N_{\mathrm{lim}}$ & - & $3 \times 10^{6}$ & - & $5 \times 10^{7}$ \\
\hline$Y_{\mathrm{NT}} Z_{\mathrm{NT}}$ & - & $2(2.5)$ & - & 1.6 \\
\hline$N_{\mathrm{P}}$ & - & $10^{3}$ & - & $10^{5}$ \\
\hline$q$ & - & $11.5(8.3)$ & - & 13.2 \\
\hline
\end{tabular}

Values in Table 6 apply for the probability of damage $P=1 \%$. Values in brackets are for steels with higher carbon content (according to ISO standard smaller value applies for the strength in the core min. $850 \mathrm{MPa}$, the higher value is for strength in the core of min. $1000 \mathrm{MPa}$ ).

The safety of differential gears, which are loaded in low cycle fatigue, can be defined by common inequalities:

$S \leq \frac{\sigma_{\lim }}{\sigma_{\mathrm{P}}}$

for bending stress safety can be calculated from the equation:

$S_{\mathrm{F}} \leq \frac{\sigma_{\mathrm{FEN}}}{\sigma_{\mathrm{FEN}} \times Y_{\mathrm{NT}}}=\frac{2 \times \sigma_{\mathrm{Flim}}}{2 \times \sigma_{\mathrm{Flim}} \times Y_{\mathrm{NT}}}=\frac{1}{Y_{\mathrm{F}}}=\frac{1}{2 \div 2,5}=0,5 \div 0,4$

and for contact:
$S_{\mathrm{H}} \leq \frac{\sigma_{\mathrm{Hlim}}}{\sigma_{\mathrm{Hlim}} \times Z_{\mathrm{NT}}}=\frac{1}{Z_{\mathrm{NT}}}=0,625$

The validity of these relationships is generally determined by the shape of the operating load spectrum. This spectrum is strongly dependent on operating conditions, type of vehicle and type of differential (axial, inter-axle). The hypothetical spectrum that was used to calculate the comparison differential gear life was created on the basis of measurements.

This calculation was performed for car applications listed in Table 5. Maximum stress $\sigma_{\max }$ was chosen at the upper limit of the highest class $(p=10)$, which corresponds to the maximum level allowable static load $\sigma_{\mathrm{p}}$ according to Table 6 . This is the highest load, if not allowing loading based on the yield strength. $\sigma_{\min }=0$ is chosen as the minimum stress of the spectrum in the lowest class $(\mathrm{p}=1)$. The numbers of spectrum cycles $N_{\mathrm{p}}$ and $N_{\mathrm{C}}$ are shown in Table 4. For minimum safety levels $S_{\mathrm{F}}$ and $S_{\mathrm{H}}$ the intensity of damage is listed in Table 8.

The intensity of damage $D_{\mathrm{H}}$ relates to the spectrum length $L_{\mathrm{p}^{\prime}}$ which is given by an estimate of the life of the vehicle (Table 5). The calculated lifetime is given by $L_{z \mathrm{v}}=L_{\mathrm{p}} / D_{\mathrm{H}}$.

When assessing the resistance of contact and bending the shape of the S-N curve must be taken into account. This depends on the number of cycles $N_{\text {lim }}$ and exponent $q$ (Table 6). At the same load bending damage will be at a far lower number of cycles than the contact damage. Circumferential and slide velocities are so small that contact damage of the differential gears cannot be expected. The intensity of differential gear damage for those vehicles where the requirements for the total lifetime are in the range $(0.5 \div 1) \times 10^{6} \mathrm{~km}$, is very low. The results of service life calculation of heavy trucks are broadly consistent with the required minimum safety levels.

\section{CONCLUSION}

The design of automobile differentials can be checked with sufficient reliability in terms of safety to fatigue limit. This assumption is confirmed by measurements and calculations. Contact safety $\left(S_{\mathrm{H}}<0.625\right)$ is not to be observed on the basis of the comparative life calculations, so can be designed to select the value of safety:

$S_{\lim }=S_{\mathrm{F}}=S_{\mathrm{H}}>0.5$

Vehicles intended for mixed traffic and terrain are equipped with a mechanical differential lock. This prevents slippage of tires with reduced adhesion. A permanent differential lock causes the formation of parasitic torques, which increase the load, and it gives rise to higher requirements for the resistance of differentials. Adequate safety for different types of vehicles can be summarized as follows: 
- personal automobile $4 \times 2$ with classical differentials without lock:

$S_{\text {lim }} \doteq 0.5-0.6$

- vans and trucks for road use without differential lock: $S_{\text {lim }} \doteq 0.6-0.7$

- trucks and vehicles for off-road and all vehicles with differential locks:

$S_{\lim }>0.7$.

TABLE 8: The calculation of lifetime for differential maximum load TABULKA 8: Výpočet životnosti pro maximální zatižení diferenciálu

\begin{tabular}{|c|c|c|c|c|c|c|c|}
\hline \multirow{3}{*}{\multicolumn{2}{|c|}{$\begin{array}{l}\text { Vehicles } \\
\text { Traffic } \\
\text { Damage }\end{array}$}} & \multicolumn{3}{|c|}{ Personal automobile } & \multicolumn{3}{|c|}{ Van } \\
\hline & & \multicolumn{3}{|c|}{ hilly } & \multicolumn{3}{|c|}{ heavy } \\
\hline & & \multicolumn{2}{|c|}{$\mathrm{F}$} & $\mathrm{H}$ & \multicolumn{2}{|c|}{$\mathrm{F}$} & $\mathrm{H}$ \\
\hline \multirow{4}{*}{$\begin{array}{l}\text { Spectrum } \\
\text { by Tables } \\
5 \text { and } 6\end{array}$} & $\sigma_{P}$ & 1840 & 2300 & 2400 & 1840 & 2300 & 2400 \\
\hline & $N_{P}$ & \multicolumn{3}{|c|}{13} & \multicolumn{3}{|c|}{50} \\
\hline & $N_{C}$ & \multicolumn{3}{|c|}{$1.3 \mathrm{e} 6$} & \multicolumn{3}{|c|}{$5 e 6$} \\
\hline & $S$ & \multicolumn{3}{|c|}{1.3} & \multicolumn{3}{|c|}{1.3} \\
\hline \multirow{3}{*}{$\begin{array}{l}\text { S-N curve } \\
\text { parameters } \\
\text { by Table } 6\end{array}$} & $\sigma_{\lim }$ & 920 & 920 & 1500 & 920 & 920 & 1500 \\
\hline & $N_{\text {lim }}$ & $3 e 6$ & $3 e 6$ & $5 \mathrm{e} 7$ & $3 e 6$ & $3 e 6$ & $5 e 7$ \\
\hline & $q$ & 11.5 & 8.3 & 13.2 & 11.5 & 8.3 & 13.2 \\
\hline \multicolumn{2}{|c|}{$\begin{array}{l}\text { required lifetime } \\
L_{P}[\mathrm{~km}]\end{array}$} & \multicolumn{3}{|l|}{250000} & \multicolumn{3}{|l|}{500000} \\
\hline \multicolumn{2}{|c|}{$\begin{array}{l}\text { intensity of } \\
\text { damage } \\
D_{H} \text { (Haibach) }\end{array}$} & 0.0369 & 0.0916 & 0.0002 & 0.1418 & 0.3523 & 0.0009 \\
\hline \multicolumn{2}{|l|}{$S_{\min }$} & 0.5 & 0.4 & 0.62 & 0.5 & 0.4 & 0.62 \\
\hline
\end{tabular}

\begin{tabular}{|c|c|c|c|c|c|c|c|}
\hline \multirow{3}{*}{\multicolumn{2}{|c|}{$\begin{array}{l}\text { vehicle } \\
\text { traffic } \\
\text { damage }\end{array}$}} & \multicolumn{6}{|c|}{ truck } \\
\hline & & \multicolumn{6}{|c|}{ combined off-road } \\
\hline & & \multicolumn{2}{|c|}{$\mathrm{F}$} & $\mathrm{H}$ & \multicolumn{2}{|c|}{$\mathrm{F}$} & $\mathrm{H}$ \\
\hline \multirow{4}{*}{$\begin{array}{l}\text { spectrum } \\
\text { by Tables } \\
5 \text { and } 6\end{array}$} & $\sigma_{P}$ & 1840 & 2300 & 2400 & 1840 & 2300 & 2400 \\
\hline & $N_{P}$ & \multicolumn{3}{|c|}{200} & \multicolumn{3}{|c|}{400} \\
\hline & $N_{C}$ & \multicolumn{3}{|c|}{$2 \mathrm{e} 7$} & \multicolumn{3}{|c|}{$4 \mathrm{e} 7$} \\
\hline & $S$ & \multicolumn{3}{|c|}{1.3} & \multicolumn{3}{|c|}{1.3} \\
\hline \multirow{3}{*}{$\begin{array}{l}\text { S-N curve } \\
\text { parameters } \\
\text { by Table } 6\end{array}$} & $\sigma_{\lim }$ & 920 & 920 & 1500 & 920 & 920 & 1500 \\
\hline & $N_{\lim }$ & $3 e 6$ & $3 e 6$ & $5 \mathrm{e} 7$ & $3 e 6$ & $3 \mathrm{e} 6$ & $5 \mathrm{e} 7$ \\
\hline & $q$ & 11.5 & 8.3 & 13.2 & 11.5 & 8.3 & 13.2 \\
\hline \multicolumn{2}{|c|}{$\begin{array}{l}\text { required lifetime } \\
L_{\mathrm{P}}[\mathrm{km}]\end{array}$} & \multicolumn{6}{|c|}{2000000} \\
\hline \multicolumn{2}{|c|}{$\begin{array}{l}\text { intensity of damage } \\
D_{\mathrm{H}} \text { (Haibach) }\end{array}$} & 0.567 & 1.4092 & 0.0035 & 1.134 & 2.8183 & 0.0069 \\
\hline \multicolumn{2}{|l|}{$S_{\min }$} & 0.5 & 0.4 & 0.62 & 0.5 & 0.4 & 0.62 \\
\hline
\end{tabular}

\section{ACKNOWLEDGEMENTS}

This article is performed at VŠB-Technical University of Ostrava. The research on VŠB-Technical University of Ostrava has been subsidized by the Czech Ministry of Education, Youth and Sports Project 1M0568 Josef Božek Research Center.

\section{REFERENCES}

[1] Folta, Z., Dejl, Z. (2011). Analýza zátěžného spektra diferenciálu osobního automobilu. D19-VCJB21A413/2011, Ostrava, 10p. (in Czech).

[2] Folta, Z., Hrudičková, M. (2008). Zpracování zátěžných spekter převodovky osobního automobilu za různých jízdních podmínek. D14-VCJB 3.3.3/2008, Ostrava, 32p. (in Czech).

[3] Moravec, V. (1972). Kontrolní výpočet děličů a diferenciálů osobních a nákladních automobilů s výjimkou samosvorných diferenciálů. Výzkumná zpráva ÚVMV Z-74/72, Praha, 16p. (in Czech).

[4] Moravec, V. (1994). Kontrolní výpočet mezinápravového diferenciálu s korunovými koly. Interní zpráva TATRA č. 06.01.815-2-57, Koprivnice, 24p. (in Czech).

[5] Deutsches Institut für Normung e. V. (1987). Tragfähigkeitsberechnung von Stirnrädern - Teil 1-5. Berlin.

[6] Deutsches Institut für Normung e. V. (1990). Tragfähigkeitsberechnung von Stirnrädern - Teil 41: Anwen dungsnormfürFahrzeuggetriebe. DIN 3990-41. Berlin.

[7] Úřad pro normalizaci a měření. (1988) Pevnostní výpočet čelních a kuželových ozubených kol. ČSN 014686 část 1-5. Praha.

[8] Český normalizační institut. (2005). Výpočet únosnosti čelních ozubených kol a prímými a šikmými zuby - Část 5: Údaje o pevnosti a kvalitě materiálů. ČSN ISO 6336-5. Praha. 